\title{
A Case Study
}

\section{Constraints perceived by farmers in production and marketing of major cole vegetable crops in Bemetara district of Chhattisgarh state}

\section{G CHANDRESH KUMAR DHURWEY, V.K. CHOUDHRY, ROPAN BANTE AND RAVI SHREY}

See end of the paper for authors' affiliations

Correspondence to :

CHANDRESH KUMAR DHURWEY

Department of Agricultural Economics, College of Agriculture, Indira Gandhi Agricultural University, RAIPUR (C.G.) INDIA

Email: dhruwe750.ag@gmail.com

\section{Paper History :}

Received : 02.08.2014;

Accepted : 17.02.2015
ABSTRACT : An attempt has been made in this paper to find out the production and marketing constraints of major cole vegetable crops. The study was conducted in Bemetara district of Chhattisgarh state with one hundred farmers who were selected randomly. Ten villages and 10 cole vegetable growers from each of selected villages were considered to collect the required information. The total numbers of constraints selected for the study were fourteen, which were categories as technical, institutional, economical and transportaional constraints. Out of these constraints, the major constraints were 'Scarcity of labour' followed by 'Problem of high infestation of different insects, pests and diseases in the crop', 'Lack of adequate training facility to farmers', 'Lack of technical knowledge', 'Lack of soil testing, facilities' and 'Lack of information regarding crop cultivation'. Some farmers perception was on constraints in marketing of vegetables and these were 'Lack of proper methods applied for harvesting of crop' followed by 'Lack of facilities regarding standardization grading', 'Lack of post harvest management' and 'Lack of regulated and co-operative market.

KEY WORDS : Production constraints, Marketing constraints, Cole crops

HOW TO CITE THIS PAPER : Dhurwey, Chandresh Kumar, Choudhry, V.K., Banty, Ropan and Shrey, Ravi (2015). Constraints perceived by farmers in production and marketing of major cole vegetable crops in Bemetara district of Chhattisgarh state. Internat. Res. J. Agric. Eco. \& Stat., 6 (1) : 193-196. 